\title{
Zinc-Chromium oxide catalyst for gas-phase ketonisation of pentanoic acid
}

\author{
Mohammed Saad Mutlaq Al-ghamdi * and Hossein Bayahia \\ Department of Chemistry, Faculty of Science, Albaha University, Albaha, PO Box 1988, 65431, \\ Kingdom of Saudi Arabia
}

\begin{abstract}
Oxides of Zinc and Chromium mixed catalyst with different atomic ratios of Zinc and Chromium were tested in the ketonisation of pentanoic acid in the gas phase. These catalysts were active to form 5-nonanone, at $300-400{ }^{\circ} \mathrm{C}$ and ambient pressure. It was found that $\mathrm{Zn}-\mathrm{Cr}$ with an atomic ratio (10:1) gave the best catalytic performance in comparison with other oxides with higher or lower atomic ratio of $\mathrm{Zn}$ and $\mathrm{Cr}$ mixed oxides, $\mathrm{ZnO}$ and $\mathrm{Cr}_{2} \mathrm{O}_{3}$. In this test, $\mathrm{Zn}-\mathrm{Cr}(10: 1)$ gave $82 \%$ of selectivity for 5-nonanone as the main product at $86 \%$ of conversion of the acid at $350^{\circ} \mathrm{C}$. The catalyst showed stable performance at the best selected conditions with a small decrease in acid conversion. For catalyst characterization, BET surface area and porosity technique, X-ray diffraction and DRIFTS of pyridine adsorption were used.
\end{abstract}

Keywords: Ketonisation; Pentanoic acid; Zinc-Chromium oxide catalyst; 5-Nonanone, gas-phase.

\section{Introduction}

The conversion of carboxylic acid to ketones, $\mathrm{CO}_{2}$ and $\mathrm{H}_{2} \mathrm{O}$ is known as the kenotic decarboxylation or ketonisation of carboxylic acid ${ }^{1-6}$ as shown in the following equation:

$$
2 \mathrm{RCOOH} \longrightarrow \mathrm{R}_{2} \mathrm{CO}+\mathrm{CO}_{2}+\mathrm{H}_{2} \mathrm{O}
$$

Additionally, the ketonisation reaction is an environmentally benign clean reaction since it gives rise to ketones without and by-product pollutants 7,8 .

The first ketonisation reaction was carried out in 1858 for the production of acetone from calcium acetate ${ }^{8}$. Ketonisation of acetic to produce acetone first took place in 1895 as the first industrial application ${ }^{9}$.

The Ketonisation reaction is a significant upgrading reaction by converting the biomass and achieving partial deoxygenation. Bio-oil compounds can be formed from fast pyrolysis of biomass and that is an example of upgrading of biomass-derived oxygenates. It is a promising reaction due to its importance in industrial processes of upgrading of biomass-derived oxygenates. It is a promising reaction due to its importance in industrial processes ${ }^{10}$.

Stonkus et al. ${ }^{11}$ used Cr-Zn-Mn mixed oxide catalyst in the ketonisation reaction of some aliphatic acids in the vapor phase in temperature ranging between $300-400{ }^{\circ} \mathrm{C}$. In this reaction and, under optimum condition of $325^{\circ} \mathrm{C}$, the maximum yield of ketones was obtained.

Several bulk and supported mixed oxide catalysts were used in the ketonisation of carboxylic acid in both liquid and gas phase reactions. Strong proton sites catalyst such as heteropoly acid catalyst were active in the ketonisation of propionic acid. $\mathrm{Ru} / \mathrm{TiO}_{2}$ catalyst has been tested in the liquid phase ketonisation of carboxylic acids and showed good catalytic activity ${ }^{8}$.

Bulk Co-Mo and $\mathrm{Co}-\mathrm{Mo} / \mathrm{Al}_{2} \mathrm{O}_{3}$ catalysts were used in the deoxygenation of propionic acid in the gas phase in the presence of $\mathrm{N}_{2}$ and $\mathrm{H}_{2}$. Co$\mathrm{Mo} / \mathrm{Al}_{2} \mathrm{O}_{3}$ and the catalysts showed a very good performance in the presence of $\mathrm{N}_{2}$ at $200-400{ }^{\circ} \mathrm{C}$ to form 3-pentanone. This catalyst gave around $44 \%$ of 3 -pentanone and only $16 \%$ of 3-pentanone which were obtained in the presence of $\mathrm{H}_{2}$ at the same conditions ${ }^{12}$.

Hexanoic acid ketonisation was carried out using the fermentation of sugars to produce high carbon numbers as diesel bendable as 6-undecanone over magnesium and manganese oxides and zirconia catalysts. It was found that the zirconia catalyst was more active than the other catalysts used. It gave $92 \%$ of ketone selectivity at $72 \%$ of acid conversion $^{13}$. For pentanoic acid ketonisation to form 5-nonanone over Ceria-zirconia at $350^{\circ} \mathrm{C}$, it was seen that the ketonisation reaction was thermodynamically favorable at $250^{\circ} \mathrm{C}$. This reaction was carried out using the same catalyst at $350^{\circ} \mathrm{C}$ and,
*Corresponding author: Mohammed Saad Mutlaq Al-ghamdi

Email address: i-73amodi@hotmail.com, hos1397@hotmail.com

DOI: http://dx.doi.org/10.13171/mjc62/01611080121-bayahia
Received September $17^{\text {th }}, 2016$

Accepted October $26^{\text {th }}, 2016$

Published November $8^{\text {th }}, 2016$ 
it was reported that the catalyst was active in the ketonisation of pentanoic acid to form 5-nonanone with $60 \%$ of yield ${ }^{14}$.

It has been reported that $90 \%$ of 5-nonanone with lower ketones such as 2-hexanone and 3heptanone were produced from an aqueous $\gamma$ valerolactone (GVL) over $\mathrm{Ce}-\mathrm{Zr}$ catalysts using single reactor. The same reaction was carried out over $0.1 \% \mathrm{Pd} / \mathrm{Nb}_{2} \mathrm{O}_{5}$ and this catalyst was selective for producing pentanoic acid ${ }^{15}$.

Carboxylic acids such as butanoic, pentanoic and hexanoic acids were tested in the ketonisation reaction over Ceria-Zirconia catalyst in the range of temperature between 548 and $623 \mathrm{~K}$. The results showed that the reactivity of ketonisation reaction decreased when increasing the length of the acids carbon chains ${ }^{16}$. These catalysts have also been reported as being active in ketonisation reactions, producing fuels by the upgrading of biomass-derived intermediates ${ }^{17}$.

Crystalline silicalite zeolite ${ }^{18}$ and $\mathrm{Zn}-\mathrm{Cr}{ }^{19}$ and its support have been used in the ketonisation of acetic and propionic acids in the gas phase at 300$450{ }^{\circ} \mathrm{C}{ }^{18,19}$. Strong proton site catalyst such as heteropoly acid was an active catalyst in the ketonisation of propionic acid in the gas phase ${ }^{20}$.

In the current work, ketonisation of pentanoic acid was carried out using $0.2 \mathrm{~g}$ of zinc-chromium mixed oxide with different atomic ratio of $\mathrm{Zn} / \mathrm{Cr}$ which was prepared by co-precipitation method in the range of $300-400{ }^{\circ} \mathrm{C}, 20 \mathrm{ml} \mathrm{min}^{-1}$ of $\mathrm{N}_{2}$ flow and 2 vol\% of acid.

\section{Experimental Section}

\section{Chemicals and materials}

The chemical and solvent used in this research work were purchased from sigma Aldrich with no further purification. For the reaction and calibration, pentanoic acid (99.0\%), 5-nonanone (>99.0\%), $\mathrm{Zn}\left(\mathrm{NO}_{3}\right)_{2} \cdot 6 \mathrm{H}_{2} \mathrm{O}, \quad \mathrm{Cr}\left(\mathrm{NO}_{3}\right)_{3} .9 \mathrm{H}_{2} \mathrm{O}, \quad \mathrm{Cu}\left(\mathrm{NO}_{3}\right)_{2} .3 \mathrm{H}_{2} \mathrm{O}$ were used.

\section{Catalyst synthesis}

Pure oxides of chromium, zinc and mixed oxides of zinc and chromium oxides were prepared by coprecipitation method as previously discussed in literature ${ }^{19,21-23}$. In this method, chromium and zinc nitrates were dissolved in distilled water. After that, $10 \mathrm{wt} \%$ aqueous ammonia was added to $0.2 \mathrm{M}$ of mixture metal nitrates solution. The mixture was stirred at $70^{\circ} \mathrm{C}$ until $\mathrm{pH}=7$ was achieved ${ }^{18,21-23}$. At $70{ }^{\circ} \mathrm{C}$, after $2-3$ hours the result was filtered and washed with distilled water until it became ammonia-free. The presence of ammonia will contaminate the system at the expense of the desired product. Next, the obtained material was air-dried at $120{ }^{\circ} \mathrm{C}$ overnight. Finally, the precipitated material was calcined at $300{ }^{\circ} \mathrm{C}$ for $3 \mathrm{~h}$ in the presence of $\mathrm{N}_{2}$ flow ${ }^{24}$.

\section{Catalyst characterisation}

For catalyst characterization, various techniques were used such as nitrogen adsorption-desorption to determine the surface area, X-ray Diffraction and DIFTR- Pyridine adsorption. The procedure for adsorbing pyridine was carried out by grounding the sample of catalyst with $\mathrm{KBr}$ as following; firstly, the mixtures were ground and pretreated up to a temperature of $150^{\circ} \mathrm{C}$ and kept constant for $1 \mathrm{~h}$. For the removal of pyridine, the sample was exposed to pyridine vapor at room temperature for 30 minutes and then heated at $150{ }^{\circ} \mathrm{C}$. Finally, DFTIR spectra were recorded for all samples used in this work ${ }^{18,24}$.

\section{Catalyst testing}

The reaction of ketonisation of pentanoic acid in the gas phase was carried out using $0.2 \mathrm{~g}$ of catalyst, $20 \mathrm{~mL} / \mathrm{min}$ of $\mathrm{N}_{2}$ flow, ambient pressure, and $2 \%$ vol of acid in the quartz fixed-bed reactor. Prior to the reaction, the amount of catalyst used has been pre-heated to the reaction condition for $1 \mathrm{~h}$. The product was analyzed by using online GC to calculate acid conversion and ketone selectivity and yield. The amount produced of $\mathrm{CO}_{2}$ was not quantified and not included in the product selectivity calculation.

\section{Result and Discussion}

\section{Catalyst characterization}

Catalyst surface area and porosity are presented in Table 1. BET results show that pure chromium with the highest surface is in comparison to zinc oxide and zinc-chromium mixed oxides.

Fig.1. shows nitrogen adsorption-desorption isotherm for the best catalyst which is bulk $\mathrm{Zn}-\mathrm{Cr}$ $(10: 1)$ oxide catalyst. This catalyst is mesoporous (between 2 to $50 \mathrm{~nm}$ pore diameter) with IV isotherm type. $\mathrm{Zn}-\mathrm{Cr}$ (10:1) mixed oxide catalyst showed an adsorption isotherm with an $\mathrm{H} 3$ hysteresis loop and a mononodal pore size distribution with pore diameter at $94 \AA^{19}$.

Table 1. Catalyst characterisation.

\begin{tabular}{|l|l|l|l|}
\hline Catalyst $^{\mathrm{a}}$ & $\begin{array}{l}\mathrm{S}_{\mathrm{BET}}{ }^{\mathrm{b}} \\
{\left[\mathrm{m}^{2} \mathrm{~g}^{-1}\right]}\end{array}$ & $\begin{array}{l}\text { Pore vol. }^{\mathrm{c}} \\
{\left[\mathrm{cm}^{3} \mathrm{~g}^{-1}\right]}\end{array}$ & $\begin{array}{l}\text { Pore size }^{\mathrm{d}} \\
{[\AA]}\end{array}$ \\
\hline $\mathrm{Cr}_{2} \mathrm{O}_{3}$ & 241 & 0.28 & 45 \\
\hline $\mathrm{Zn}-\mathrm{Cr}(1: 30)$ & 230 & 0.35 & 56 \\
\hline $\mathrm{Zn}-\mathrm{Cr}(1: 20)$ & 227 & 0.36 & 54 \\
\hline $\mathrm{Zn}-\mathrm{Cr}(1: 10)$ & 216 & 0.33 & 57 \\
\hline $\mathrm{Zn}-\mathrm{Cr}(1: 6)$ & 196 & 0.35 & 56 \\
\hline $\mathrm{Zn}-\mathrm{Cr}(1: 1)$ & 140 & 0.13 & 71 \\
\hline $\mathrm{Zn}-\mathrm{Cr}(10: 1)$ & 46 & 0.11 & 89 \\
\hline $\mathrm{Zn}-\mathrm{Cr}(20: 1)$ & 15 & 0.02 & 85 \\
\hline $\mathrm{Zn}-\mathrm{Cr}(30: 1)$ & 12 & 0.02 & 88 \\
\hline $\mathrm{ZnO}$ & 14 & 0.03 & 97 \\
\hline
\end{tabular}

${ }^{\mathrm{a}}$ Zinc chromium fresh catalyst, calcination condition ( $300^{\circ} \mathrm{C}$ and $\mathrm{N}_{2}$ flow for $3 \mathrm{~h}$ ); ${ }^{\mathrm{b}}$ BET surface area; ${ }^{\mathrm{c}}$ single point total pore volume; ${ }^{\mathrm{d}}$ average BET pore diameter. 


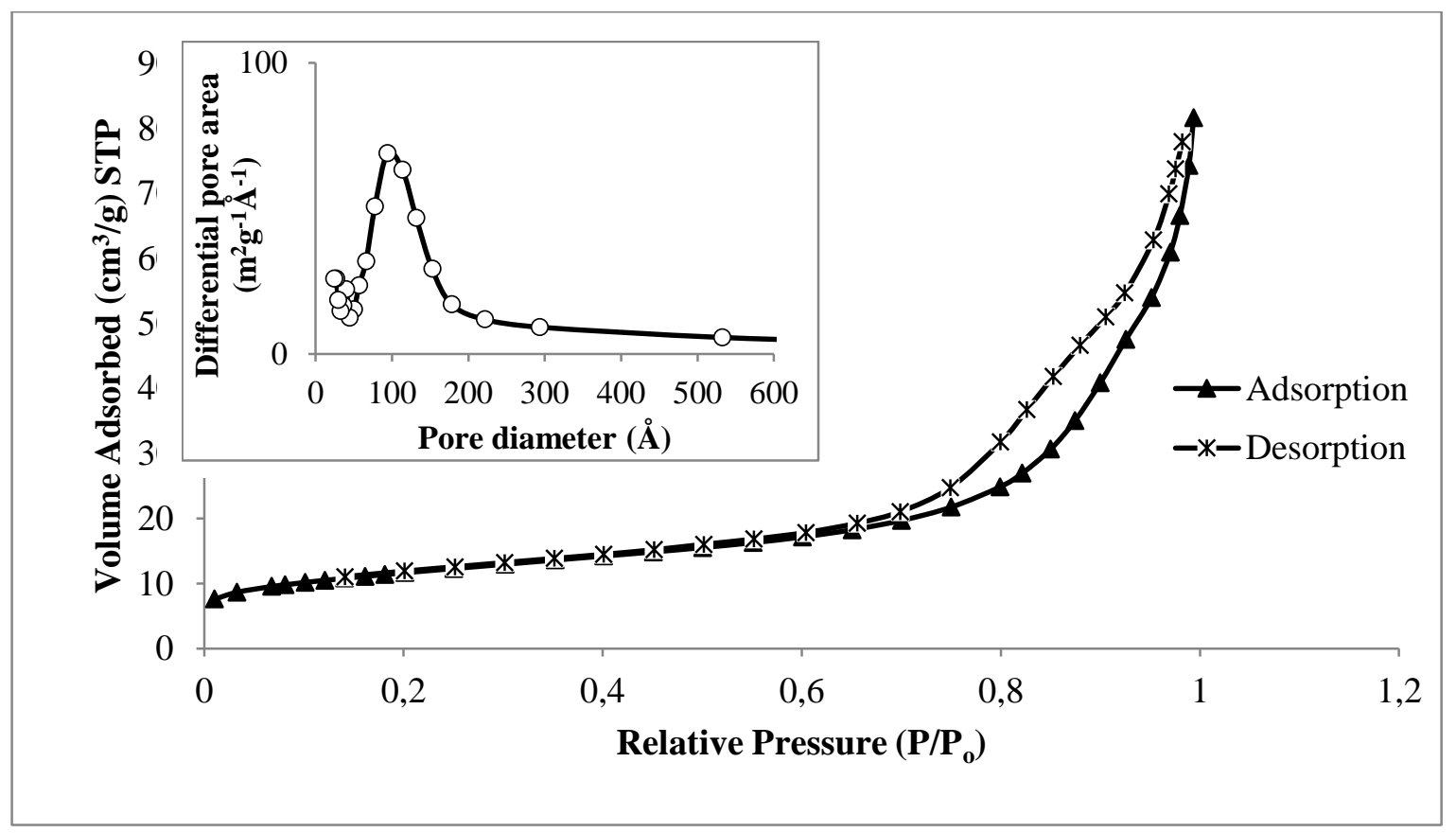

Figure 1. Fresh $\mathrm{Zn}-\mathrm{Cr}$ (10:1) nitrogen adsorption and desorption isotherm.

\section{X-ray diffraction of zinc-chromium catalyst}

$\mathrm{X}$-ray diffraction for pure zinc and chromium and zinc-chromium mixed oxide catalysts calcined at $300{ }^{\circ} \mathrm{C}$ in the presence of $\mathrm{N}_{2}$ shows that rich zinc catalyst is crystalline. However, rich chromium catalyst is amorphous as shown in Fig. 2.

It has been reported by Hossein Bayahia et. al. ${ }^{19}$ that $\mathrm{Zn}-\mathrm{Cr}$ mixed oxides calcined at $>350{ }^{\circ} \mathrm{C}$ exhibited $\mathrm{Cr}_{2} \mathrm{O}_{3}$ and $\mathrm{ZnCr}_{2} \mathrm{O}_{4}$ spinel crystalline phase.

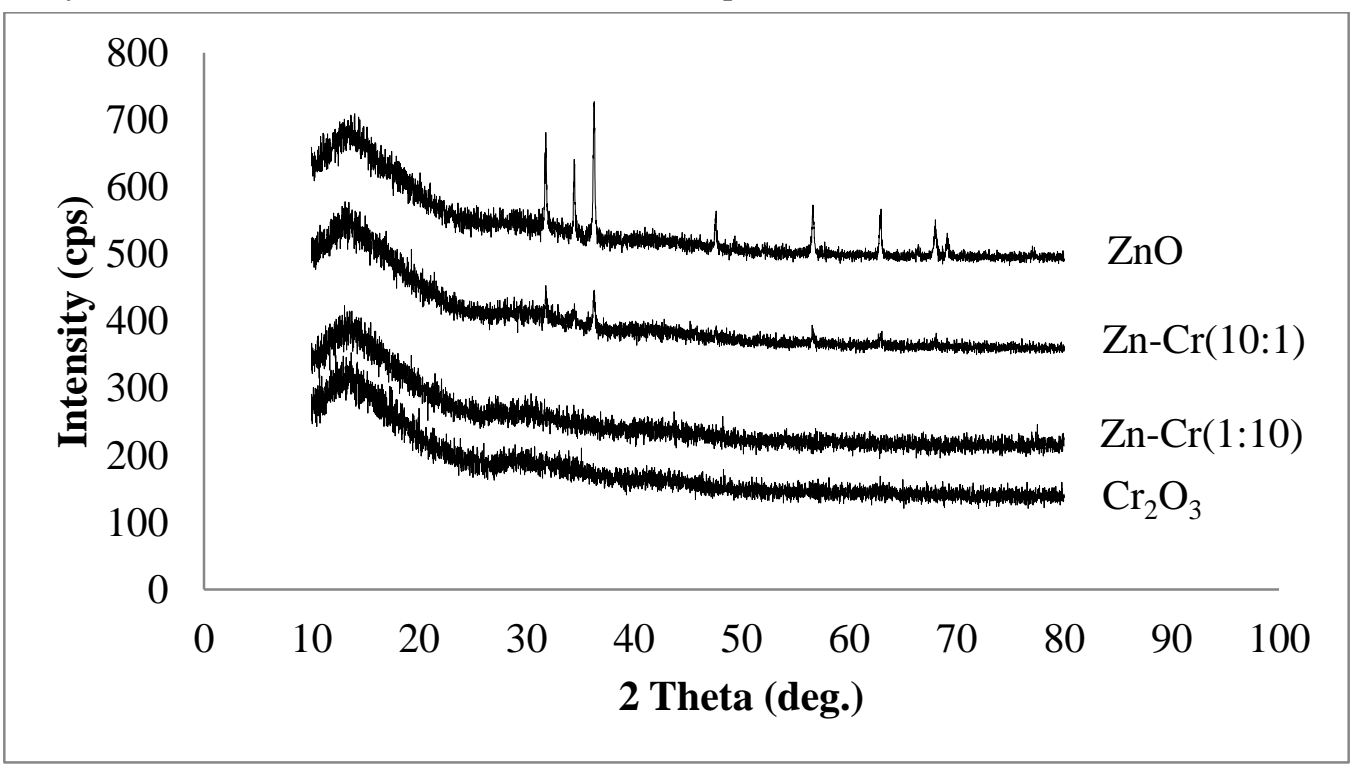

Figure 2. X-ray diffraction for the zinc-chromium catalyst.

\section{Catalyst acidity}

The acidity of zinc-chromium catalyst has been measured by DFTIR study of pyridine adsorption as shown in Fig. 3. The bands at 1540 and $1450 \mathrm{~cm}^{-1}$ are attributed to BrØnsted and Lewis acid sites respectively ${ }^{19,24}$. Moreover, the band at $1490 \mathrm{~cm}-1$ is attributed to the adsorption of pyridine on BrØnsted and Lewis acid sites together as well as Hydrogenbonded pyridine. All catalysts of $\mathrm{Cr}_{2} \mathrm{O}_{3}, \mathrm{Zn}-\mathrm{Cr}$ (10:1) and $\mathrm{ZnO}$ with strong bands at $1450 \mathrm{~cm}^{-1}$ have Lewis acid sites. However, only pure chromium and $\mathrm{Zn}-\mathrm{Cr}$ (10:1) mixed oxides have a small quantity of BrØnsted acid sites in their spectra, while, $\mathrm{ZnO}$ has no BrØnsted acid sites (Fig. 3). Both Lewis and Brønsted acid sites are responsible for the ketonisation of pentanoic acid to for 5-nonanone as IR patterns for pyridine adsorption show (Fig. 3) and this in agreement with the literature ${ }^{25}$. This catalytic property can affect the catalytic activity. 


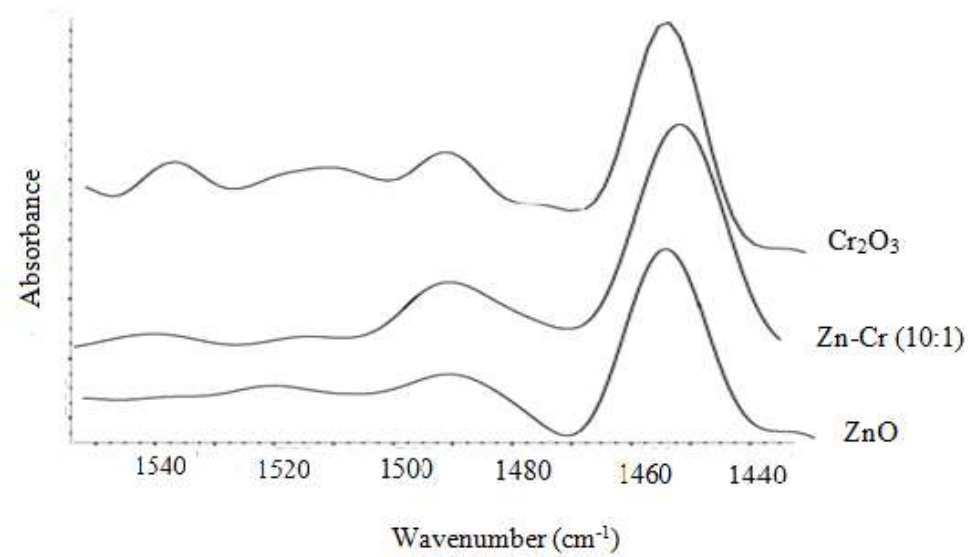

Figure 3 DRIFT spectra of pyridine adsorption for zinc-chromium catalysts.

\section{Catalyst performance}

Table 2 illustrates catalytic ketonisation of pentanoic acid over zinc-chromium catalysts. The reaction was carried out at $350{ }^{\circ} \mathrm{C}$, with $20 \mathrm{mLmin}^{-1}$ flow of $\mathrm{N}_{2}, 0.2$ of catalyst and $2 \%$ vol of acid used. All catalysts were active, but zinc-chromium (10:1) catalyst was the most active one. The catalyst gave $82 \%$ of selectivity for 5 -nonanone at $86 \%$ conversion (70.52\% yield) with only $4 \%$ of hydrocarbons produced. These hydrocarbons might be $\mathrm{C} 1-\mathrm{C} 4$ or higher alkanes and alkenes ${ }^{15}$ obtained by acidcatalysted craking of 5-nonanoe ${ }^{19}$. $\mathrm{CO}$ and $\mathrm{CO}_{2}$ were not monitored and the unknown remaining might be some deoxygenates products ${ }^{19}$. It can be noted that zinc and chrome ratio play a role in ketonisation of pentanoic acid. The acid conversion and ketone selectivity are slightly decreased by increasing the ration of $\mathrm{Zn}$ to $\mathrm{Cr}$ and this is in agreement with previous report ${ }^{19}$.

Table 2. Ketonisation of pentanoic acid over $0.2 \mathrm{~g}$ Zinc-Chromium mixed oxide catalysts at $350^{\circ} \mathrm{C}, 1 \mathrm{bar}, 2$ vol\% $20 \mathrm{mLmin}^{-1} \mathrm{~N}_{2}, 4.0 \mathrm{~h} \mathrm{~g} \mathrm{~mol}^{-1}$ space-time, and $4 \mathrm{~h} \mathrm{TOS}$.

\begin{tabular}{|l|l|l|l|l|}
\hline \multirow{2}{*}{ Catalyst } & Conversion (\%) & Selectivity (\%) & \multicolumn{2}{l|}{} \\
\cline { 3 - 5 } & & $5-$ Nonanone & Hydrocarbons & Unknown \\
\hline $\mathrm{Cr}_{2} \mathrm{O}_{3}$ & 82 & 45 & 9 & 46 \\
\hline $\mathrm{Zn}-\mathrm{Cr}(1: 30)$ & 76 & 60 & 11 & 29 \\
\hline $\mathrm{Zn}-\mathrm{Cr}(1: 20)$ & 75 & 64 & 13 & 23 \\
\hline $\mathrm{Zn}-\mathrm{Cr}(1: 10)$ & 71 & 58 & 9 & 38 \\
\hline $\mathrm{Zn}-\mathrm{Cr}(1: 6)$ & 68 & 51 & 7 & 42 \\
\hline $\mathrm{Zn}-\mathrm{Cr}(1: 3)$ & 82 & 42 & 11 & 47 \\
\hline $\mathrm{Zn}-\operatorname{Cr}(1: 1)$ & 78 & 49 & 9 & 42 \\
\hline $\mathrm{Zn}-\mathrm{Cr}(10: 1)$ & 86 & 82 & 4 & 14 \\
\hline $\mathrm{Zn}-\mathrm{Cr}(20: 1)$ & 84 & 52 & 9 & 39 \\
\hline $\mathrm{Zn}-\operatorname{Cr}(30: 1)$ & 79 & 61 & 7 & 32 \\
\hline $\mathrm{ZnO}$ & 84 & 56 & 11 & 33 \\
\hline
\end{tabular}

Table 3 Zinc-Chromium (10:1) oxide catalyst performance in pentanoic acid ketonisation, 1 bar, $20 \mathrm{mLmin}^{-1}$ $\mathrm{N}_{2}, 0.2 \mathrm{~g}$ of catalyst, $2 \mathrm{vol} \%$ of acid, $4.0 \mathrm{~h} \mathrm{~g} \mathrm{~mol}^{-1}$, and $4 \mathrm{~h} \mathrm{TOS}$.

\begin{tabular}{|l|l|l|l|l|}
\hline Temperature, ${ }^{\circ} \mathrm{C}$ & Conversion (\%) & Selectivity (\%) & \multicolumn{3}{|l|}{} \\
\cline { 3 - 5 } & & 5 -nonanone & Hydrocarbons & Unknown \\
\hline 300 & 3 & 94 & 2 & 4 \\
\hline 320 & 42 & 87 & 6 & 7 \\
\hline 350 & 86 & 82 & 4 & 32 \\
\hline 380 & 88 & 59 & 9 & 30 \\
\hline 400 & 95 & 15 & 55 & \\
\hline
\end{tabular}

\section{Effect of temperature}

Table 3 shows the ketonisation of pentanoic acid in the range of temperature $\left(300-400{ }^{\circ} \mathrm{C}\right)$. At $300{ }^{\circ} \mathrm{C}$, only $3 \%$ of pentanoic acid was converted to 5-nonanone. However, the conversion of acid increased with increasing the temperature from 300 to $400{ }^{\circ} \mathrm{C}$. At $350{ }^{\circ} \mathrm{C}$ the catalyst showed the best performance. Increasing the temperature to $400^{\circ} \mathrm{C}$, acid conversion reached $95 \%$, but 5-nonanot selectivity decreased to only $15 \%$ and the highest amount of hydrocarbons formed by cracking. Generally, ketonisation reaction was affected by 
temperature. Increasing the temperature increased the activity, and it can be seen that the selectivity of ketone was reduced.

Activation Energy for ketonisation of pentanoic acid over Zinc-Chromium oxide (10:1)
Activation energy for the pentanoic acid over 0.2 g zinc-chromium catalyst $(10: 1)$ at $300-400{ }^{\circ} \mathrm{C}$ under $20 \mathrm{~mL} / \mathrm{min}$ of $\mathrm{N}_{2}$ flow and 2 vol \% of acid was measured as shown in fig. 4 . The activation energy is $100 \mathrm{~kJ} \mathrm{~mol}^{-1}$

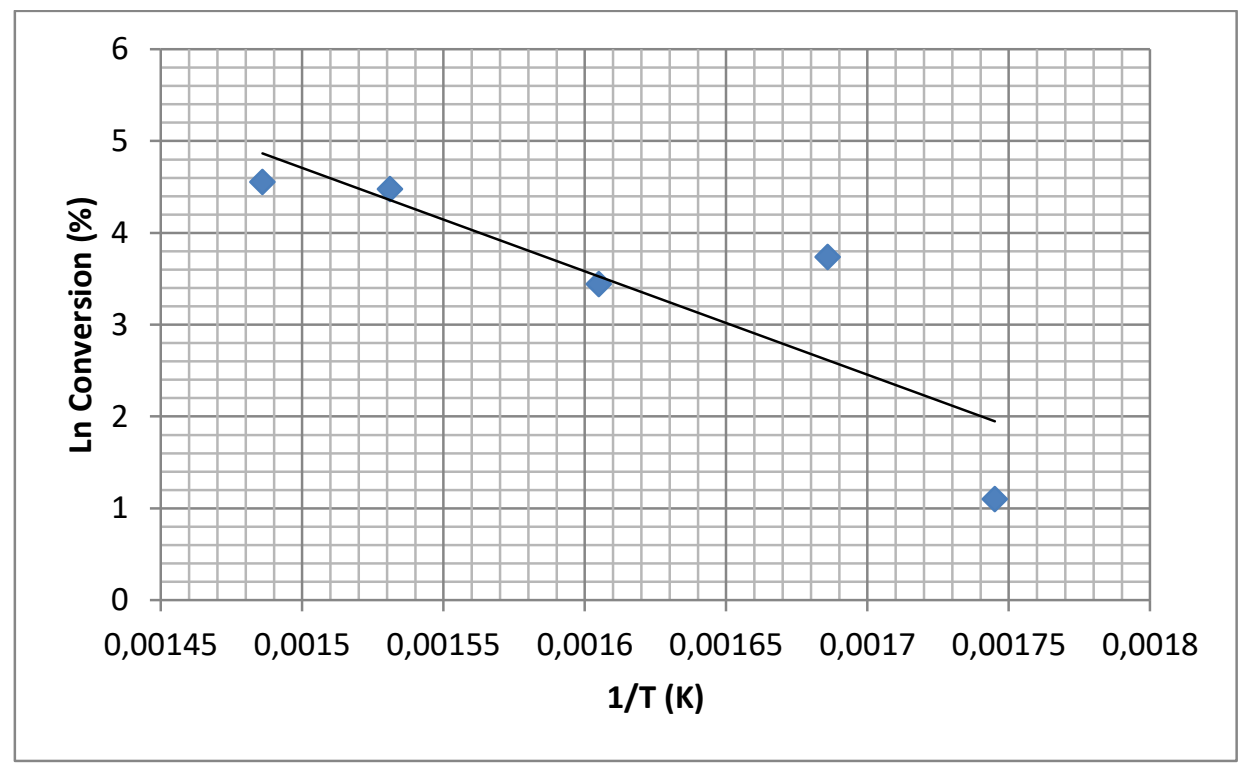

Figure 4. Arrhenius plots of ketonisation of pentanoic acid over Zinc-Chromium (10:1) oxide ( $300-400^{\circ} \mathrm{C}, 1$ bar pressure, $0.2 \mathrm{~g}$ catalyst, $20 \mathrm{~mL} \mathrm{~min}^{-1} \mathrm{~N}_{2}$ flow rate and 2 vol $\%$ of pentanoic acid).

Stability of Zinc-Chromium catalyst for ketonisation of pentanoic acid

Zinc-Chromium (10:1) oxide showed the best performance at $350{ }^{\circ} \mathrm{C}, 20 \mathrm{~mL}$ of $\mathrm{N}_{2}$ flow and 20 vol\% of pentanoic acid in the ketonisation of pentanoic acid. In this case, the catalyst was tested for at least 20 hours' time on stream. The catalyst reached the steady state from first hour TOS. The catalyst was stable with a small decrease in acid conversion. After 18 hours, pentanoic acid conversion decreased from 86 to $73 \%$ as shown in Fig. 5. The decrease in catalytic performance with time could be due to the deposition of coke. The catalyst was regenerated by heating under oxidizing conditions. The regenerated catalyst showed similar activity as the fresh catalyst.

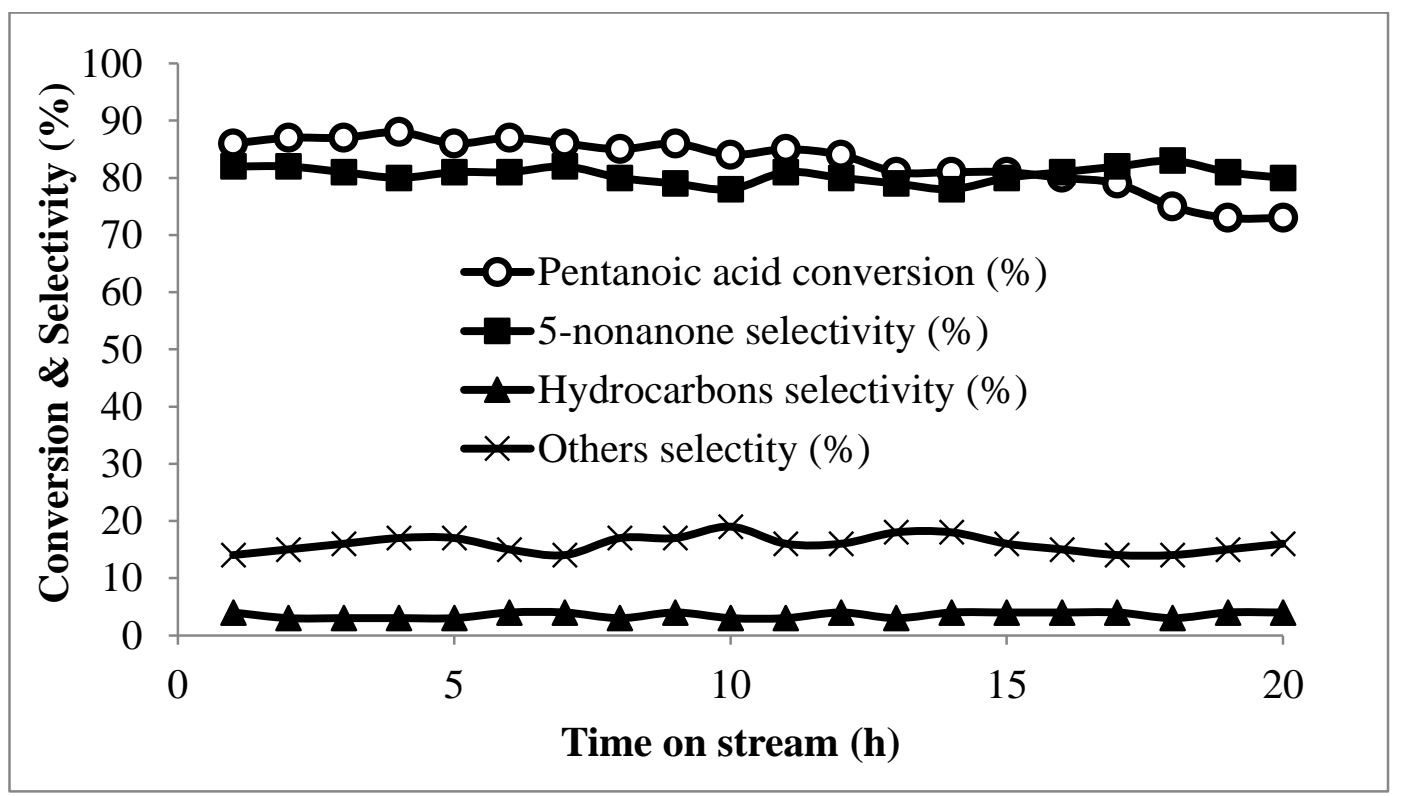

Figure 5. Ketonisation of pentanoic acid on Zinc-Chromium $(10: 1)$ oxide $\left(350^{\circ} \mathrm{C}, 1\right.$ bar pressure, $0.2 \mathrm{~g}$ catalyst, $2 \mathrm{vol} \%$ of acid, $20 \mathrm{~mL} \mathrm{~min}^{-1} \mathrm{~N}_{2}$ flow rate and $4.0 \mathrm{~h} \mathrm{~g} \mathrm{~mol}^{-1}$ space-time).

This work has demonstrated that zinc-chromium oxide catalysts are active and durable for the ketonisation of pentanoic acid in the gas phase at $300-400{ }^{\circ} \mathrm{C}$ in the flow of $\mathrm{N}_{2}$ and at ambient 
pressure. Zinc-chromium (10:1) oxide catalysts showed the best catalytic activity with around $71 \%$ of 5-nonanone yield. This catalyst was stable for 20 $\mathrm{h}$ TOS with small deactivation due to the coke deposition on the catalyst surface. BET, XRD, DRIFTS pyridine adsorption techniques were used for the characterization of the catalysts used in this work.

\section{Acknowledgment}

The authors would like to thank Albaha University, Albaha, Saudi Arabia for providing facilities at Physical Chemistry Laboratory in the Faculty of Science at the University City in Alaqeeq. Thanks are due to The University of Liverpool for providing GC equipment. Finally, sincere thanks to Mr. Joel Mcglone, PhD student at the University of Liverpool for proofreading this article.

\section{References}

1- A. Corma, S. Iborra and A. Velty, Chem. Rev., 2007, 107, 2411-2502.

2- E. L. Kunkes, D. A. Simonetti, R. M. West, J. C. Serrano-Ruiz, C. A. Gärtner and J. A. Dumesic, Science, 2008, 322, 417-421.

3- M. Snåre, I. Kubičková, P. Mäki-Arvela, K. Eränen and D. Y. Murzin, Ind. Eng. Chem. Res., 2006, 45, 5708-5715.

4- H. Bernas, K. Eränen, I. Simakova, A. R. Leino, K. Kordás, J. Myllyoja, P. Mäki-Arvela, T. Salmi and D. Y. Murzin, Fuel, 2010, 89, 2033-2039.

5- P. T. Do, M. Chiappero, L. L. Lobban and D. E. Resasco, Catal. Lett., 2009, 130, 9-18.

6- J. G. Immer, M. J. Kelly and H. H. Lamb, Appl. Catal. A, 2010, 375, 134-139.

7- M. Renz, Eur. J. Org. Chem., 2005, 979-988.

8- T. N. Pham, T. Sooknoi, S. P. Crossley and D. E. Resasco, ACS Catal., 2013, 3, 2456-2473.

9- A. D. Murkute, J. E. Jackson and D. J. Miller, J. Catal., 2011, 278, 189-199.

10- T. Pham, D. Shi and D. Resasco, Top. Catal., 2014, 57, 706-714.
11- W. Stonkus, J. Yuskovets, L. Leite, M. Fleisher, K. Edolfa, I. Liepina, A. Mishnev and A. Shmidlers, Russ. J. Gen. Chem., 2011, 81, 1523-1528.

12- H. Bayahia, Asian J. Chem., 2016, 28, 27442748.

13- Yunsu Lee, Jae-Wook Choi, Dong Jin Suh, Jeong-Myeong Ha, Chang-Ha Lee, Appl. Catal. A, 2015, 506, 288-293.

14- Paolo Fornasiero, Paolo Fornasiero, Mauro Graziani, Paolo Fornasiero, Mauro Graziani, Mauro Graziani, Renewable Resources and Renewable Energy: A Global Challenge, Second Edition, 2011, p. 64.

15- Kai Yan, Yiyi Yang, Jiajue Chai, Yiran Lu, Appl. catal. B, 2015, 179, 292-304.

16- Christian A. Gaertner, Juan Carlos SerranoRuiz, Drew J. Braden, and James A. Dumesic, Ind. Eng. Chem. Res. 2010, 49, 6027-6033.

17- Ryan W. Snell and Brent H. Shanks, ASC Catal., 2014, 4, 512-518.

18- H. Bayahia, E. Kozhevnikova and I. Kozhevnikov, Chem. Commun, 2013, 49, 3842-3844.

19- H. Bayahia, E. F. Kozhevnikova and I. V. Kozhevnikov, Appl. Catal. B, 2015, 165, 253259.

20- M. A. Alotaibi, E. F. Kozhevnikova and I. V. Kozhevnikov, Appl. Catal. A, 2012, 447-448, 32-40.

21- F. Al-Wadaani, E. F. Kozhevnikova and I. V. Kozhevnikov, J. Catal., 2008, 257, 199-205.

22- F. Al-Wadaani, E. F. Kozhevnikova and I. V. Kozhevnikov, Appl. Catal. A, 2009, 363, 153156.

23- Hossein Bayahia, PhD thesis, the University of Liverpool (2015).

24- A.M. Alsalme, P.V. Wiper, Y.Z. Khimyak, E.F. Kozhevnikova, I.V. Kozhevnikov, J. Catal., 2010, 276, 181-189.

25- H. Knözinger, in: G. Ertl, H. Knözinger, F. Schüth, J. Weitkamp (Eds.), Handbookof Heterogeneous Catalysis, vol. 2, Wiley-VCH, 2008, p. 1154. 